\title{
British culture and the end of empire
}

EDITED BY STUART WARD

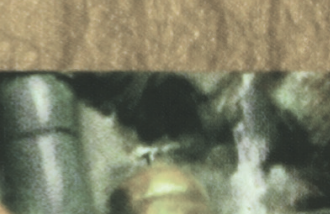

4 ses

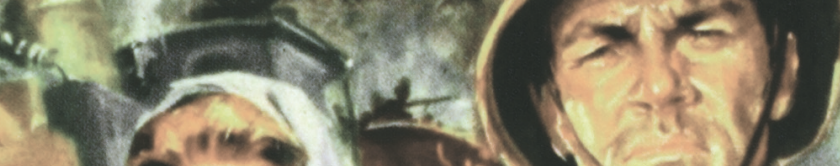

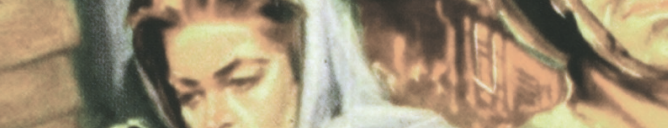

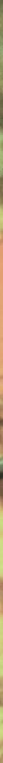




\section{IMPERIALS INM}

General editor John M. MacKenzie

When the 'Studies in Imperialism' series was founded by Professor John M. MacKenzie more than thirty years ago, emphasis was laid upon the conviction that imperialism as a cultural phenomenon had as significant an effect on the dominant as on the subordinate societies'. With well over a hundred titles now published, this remains the prime concern of the series. Cross-disciplinary work has indeed appeared covering the full spectrum of cultural phenomena, as well as examining aspects of gender and sex, frontiers and law, science and the environment, language and literature, migration and patriotic societies, and much else. Moreover, the series has always wished to present comparative work on European and American imperialism, and particularly welcomes the submission of books in these areas. The fascination with imperialism, in all its aspects, shows no sign of abating, and this series will continue to lead the way in encouraging the widest possible range of studies in the field. Studies in Imperialism is fully organic in its development, always seeking to be at the cutting edge, responding to the latest interests of scholars and the needs of this everexpanding area of scholarship.

\section{British culture and the end of empire}


Stuart Ward - 9781526119629 Downloaded from manchesterhive.com at $04 / 26 / 2023$ 07:32:22AM 


\section{British culture \\ and the end of empire \\ edited by Stuart Ward}

MANCHESTER

UNIVERSITY PRESS

Manchester 
Copyright (C) Manchester University Press 2001

While copyright in the volume as a whole is vested in Manchester University Press, copyright in individual chapters belongs to their respective authors, and no chapter may be reproduced in whole or in part without the express permission in writing of both author and publisher.

Published by Manchester University Press

Altrincham Street, Manchester, M1 7JA, UK

www.manchesteruniversitypress.co.uk

British Library Cataloguing-in-Publication Data

A catalogue record for this book is available from the British Library

Library of Congress Cataloging-in-Publication Data

A catalog record for this book is available from the Library of Congress

ISBN 0719060486 paperback

First published 2001

First digital, on-demand edition produced by Lightning Source 2006

The publisher has no responsibility for the persistence or accuracy of URLs for any external or third-party internet websites referred to in this book, and does not guarantee that any content on such websites is, or will remain, accurate or appropriate. 